
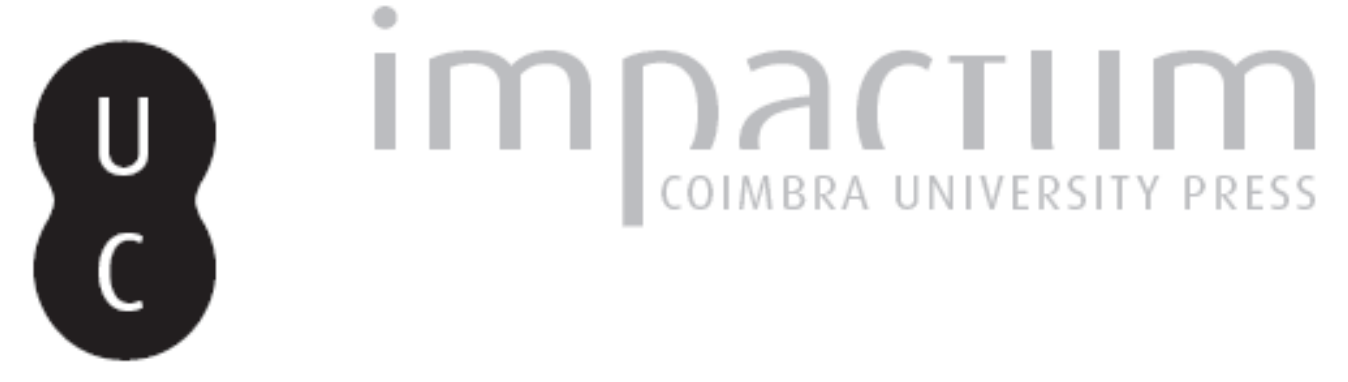

\title{
A vida como deserto nas Enarrationes in psalmos de Agostinho
}

Autor(es): Barbosa, Diogo Morais

Publicado por: Faculdade de Letras da Universidade de Coimbra, Instituto de Estudos

URL

persistente:

URI:http://hdl.handle.net/10316.2/29409

DOI:

DOI:http://dx.doi.org/10.14195/0872-0851_42_3

Accessed : $\quad$ 26-Apr-2023 14:12:57

A navegação consulta e descarregamento dos títulos inseridos nas Bibliotecas Digitais UC Digitalis, UC Pombalina e UC Impactum, pressupõem a aceitação plena e sem reservas dos Termos e Condições de Uso destas Bibliotecas Digitais, disponíveis em https://digitalis.uc.pt/pt-pt/termos.

Conforme exposto nos referidos Termos e Condições de Uso, o descarregamento de títulos de acesso restrito requer uma licença válida de autorização devendo o utilizador aceder ao(s) documento(s) a partir de um endereço de IP da instituição detentora da supramencionada licença.

Ao utilizador é apenas permitido o descarregamento para uso pessoal, pelo que o emprego do(s) título(s) descarregado(s) para outro fim, designadamente comercial, carece de autorização do respetivo autor ou editor da obra.

Na medida em que todas as obras da UC Digitalis se encontram protegidas pelo Código do Direito de Autor e Direitos Conexos e demais legislação aplicável, toda a cópia, parcial ou total, deste documento, nos casos em que é legalmente admitida, deverá conter ou fazer-se acompanhar por este aviso.

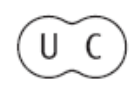




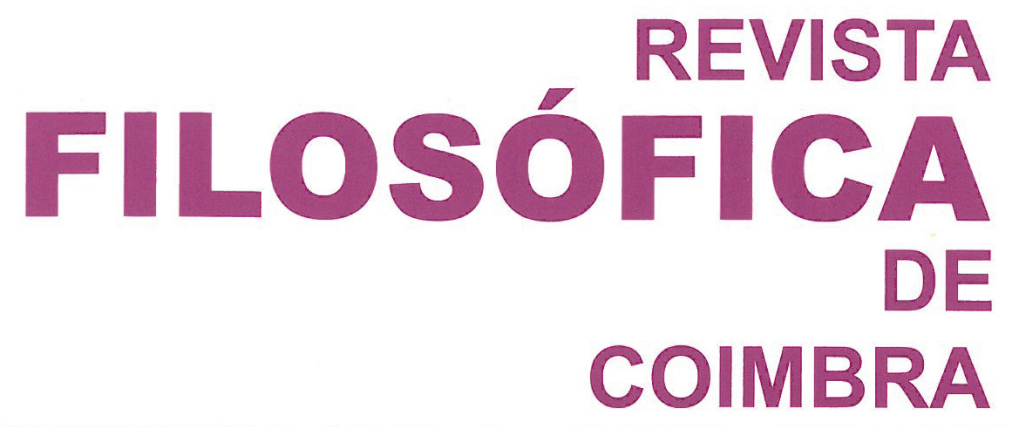

vol. 21 - número 42 - outubro 2012

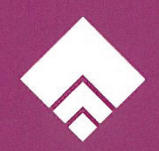




\section{A VIDA COMO DESERTO NAS ENARRATIONES IN PSALMOS DE AGOSTINHO ${ }^{1}$}

DIOGO MORAIS BARBOSA*

\section{Introdução. O deserto como categoria existencial}

A descrição da vida como deserto não constitui uma abordagem facultativa à identificação do Homem, tal como esta se acha feita nas Enarrationes in psalmos de Agostinho. Na verdade, trata-se de uma descrição que, de uma forma ou de outra, perpassa toda aquela obra. Está sempre aí. Ou de modo ostensivo ou como pano de fundo. Mas sempre presente. Segundo Agostinho, pode-se até mesmo dizer (sem temor de exagero) que é a compreensão da vida como deserto que desencadeia os salmos, na sua componente humana.

Este facto é claro no início do sermão ao salmo 26. Agostinho pergunta se a voz dos salmos é do Espírito ou do Homem. E responde: «ambas as coisas são verdadeiras. A voz é nossa e não é nossa; a voz é do Espírito de Deus e não é dele. A voz é do Espírito de Deus, pois não a diríamos se ele não a inspirasse; mas não é dele, pois ele não é nem infeliz nem atribulado. E estas vozes são dos miseráveis e dos atribulados. São sem dúvida nossas, porque são vozes indicadoras da nossa miséria; mas não são nossas, porque até mesmo gemer é recebido como dom dele». ${ }^{2}$ Quer

* LIF (Secção de Filosofia, da Faculdade de Letras da Universidade de Coimbra).

1 Uma primeira versão deste artigo foi apresentada ao seminário Deus, Homem, Mundo em Agostinho de Hipona, que teve lugar na Faculdade de Letras da Universidade do Porto, durante o mês de Janeiro de 2012. Agradeço ao Prof. Doutor Mário Jorge de Carvalho por me ter facultado o seu artigo «Imago dei: alguns aspectos da identificação do humano segundo Agostinho» (por editar). Este artigo foi muito importante para a minha interpretação. Como é óbvio, os erros interpretativos são meus. Agradeço, também, ao Prof. Doutor Mário Santiago de Carvalho e ao Prof. Doutor Nuno Ferro, pelas suas sugestões após a leitura do texto.

${ }^{2}$ AGOSTINHO, Enarrationes in psalmos, 26, p. II, n. ${ }^{\circ}$ 1: [...] utrumque verum est, et nostram esse vocem, et nostram non esse; et Spiritus Dei esse vocem, et ipsius non 
dizer, a componente humana a desencadear os salmos é, justamente, a categoria existencial da miséria: dos trabalhos, da aridez, da sede - do deserto. Ora, se se tiver em linha de conta que os salmos são expressão de toda uma antropologia, perceber-se-á que não está em causa uma problematização de carácter parcial, circunscrito ou regional. Não está em jogo uma indagação a que se vai de quando em vez, e que existencialmente não interessa, a ponto de poder ser posta de lado. Não: está em causa um enigma em que tudo se acha envolvido. Todos os homens, e o Homem todo. Numa palavra: está em jogo a própria identificação do Homem enquanto Homem.

Mas o trecho acima citado reflecte um outro aspecto decisivo, ligado ao que acabou de ser dito e que importa destacar: a configuração da vida como deserto não decorre necessariamente de um acaso nefasto ocorrido a uma determinada pessoa, num tempo determinado e num determinado lugar. De facto, nem mesmo a voz de miséria, ${ }^{3}$ que se faz ouvir nos salmos, é inteiramente subjectiva ou pessoal. Porque tem como gerador primeiro um outro que não o Homem, um outro que não o desterrado. É certo que existe uma experiência de deserto que decorre de circunstancialismos subjectivos ou pessoais. ${ }^{4}$ Sem dúvida que existem gemidos de circunstância. ${ }^{5}$ É indubitável que ocorrem tribulações criadas por acontecimentos concretos. ${ }^{6}$ No entanto, este não é, de todo, o aspecto fundamental que as Enarrationes pretendem mostrar. A voz dos salmos que Agostinho intenta pôr a descoberto é a voz da miséria na sua dimensão autêntica - isto é, na sua dimensão constitutiva. É a voz que tem como princípio, não o Homem mas sim o próprio Espírito. Espírito que sobredimensiona mas que, justamente ao e por sobredimensionar, instaura em todos os homens uma fortíssima componente de falta, de escassez ou exiguidade - de «ainda não». É, portanto, a voz desencadeada pelo facto inexpedível e inextirpável de o Homem se encontrar desde sempre já, e de cada vez, a habitar aquilo que Agostinho tanta vezes denomina «região da miséria» («regio egestatis»). ${ }^{7}$ Uma região em que até mesmo as coisas doces da vida são

esse. Spiritus Dei vox est, quia ista nisi illo inspirante non diceremus: ipsius autem non est, quia ille nec miser est, nec laborat. Istce autem voces miserorum et laborantium sunt. Rursus nostræ sunt, quia voces sunt indicantes miseriam nostram: item non sunt nostræ, quia ex dono eius vel gemere meremur». Itálico meu. As traduções são da minha autoria.

3 Cfr. Ibidem.

${ }^{4}$ Cfr. $i b i, 54$, n. ${ }^{\text {os }} 8-9 ;$; ibi, 64, n. ${ }^{\circ} 11$ e n. ${ }^{\circ} 17$; e ibi, 67, n. ${ }^{\circ} 9$.

5 Cfr. ibi, 110, n. $^{\circ} 1$.

${ }^{6}$ Cfr. $i b i, 59$, n. $^{\circ} 2$.

7 Cfr., por exemplo, ibi, 84, n. ${ }^{\circ}$ 7. A propósito de «miséria» («egestas»), cfr., também, $i b i, 18$, p. II, n. ${ }^{\circ} 3$; ibi, 30, p. I, n. ${ }^{\circ} 11 ; i b i, 84$, n. $^{\circ} 7$; ibi, 101, n. ${ }^{\circ} 3$; e ibi, 108, n. ${ }^{\circ} 15$. 
tragadas com amargura ${ }^{8}$ na justa medida em que o deserto autêntico não decorre de determinadas eventualidades negativas - antes é condição do homem cativo, inquilino em terras áridas e sedentas, que são incapazes de chover sobre si mesmas (também em época de bonança). ${ }^{9}$

É assim afastada, pela própria pena de Agostinho, uma qualquer leitura psicológica da descrição da vida como deserto. Repita-se: a configuração autêntica da vida como deserto não é iniciativa do Homem, mas sim do próprio Espírito. Não é resultado de um evento sucedido num tempo e num espaço concretos. Não é, pois, consequência de uma mente turvada pela activação de possibilidades que poderiam não ter sido activadas; que são ou foram mas poderiam não ser ou não ter sido. Pode até mesmo acontecer - mais ainda: tende a acontecer, primariamente e o mais das vezes - que a vida como deserto nem sequer seja experimentada como tal. Também então a categoria existencial continua a vigorar, pese embora o ponto de vista distraído de quem julga viver na abundância. ${ }^{10}$

\section{A imagem de Deus como sobredimensionamento do Homem}

Ao propor-se estudar a descrição da vida como deserto segundo as Enarrationes, o investigador depara-se com um sem número de dificuldades. Cabe destacar duas: desde logo, o facto de aquela descrição perpassar toda a obra torna a selecção dos textos algo muito subjectivo, mormente se se pensar que as Enarrationes têm dimensões muito consideráveis. Mas a principal dificuldade nem é esta. O grande problema é que tal descrição não pode ser estudada isoladamente, de modo abstracto, sem se tomar em consideração a complexa antropologia latente no comentário de Agostinho aos salmos. Ora, ao acrescentar-se ao exposto que se pretende escrever um artigo (e não um livro), pode-se imaginar o desespero que é tentar (passe a expressão) "meter o Rossio na Bestesga"...

Face a estes obstáculos, das duas uma: ou bem que se começava medias in res, com o perigo de se perder o pouco fio da meada; ou bem que se constituía um como que "retrato robot" da concepção augustiniana, isto

$8 \mathrm{Ibi}, 51, \mathrm{n}^{\mathrm{o}}$ 18: «O mundo é amargo, mas o teu nome é doce. E se existem algumas coisas doces no mundo, são todavia digeridas com amargura». («Amarum est sæculum, sed nomen tuum iucundum. Et si dulcia quædam sunt in sæculo, sed cum amaritudine digeruntur».)

9 As noções de homem cativo, inquilino, terra árida e incapacidade de esta chover sobre si serão noções retomadas, numa fase mais adiantada da exposição. Daí não se referir já as passagens onde são focadas.

${ }^{10}$ Cfr., por exemplo, ibi, 29, p. II, n. ${ }^{\circ} 17$; e $i b i, 122$, n. $^{\circ} 7$. 
é, se ia conjugando as peças uma a uma, tanto quanto possível. Optou-se pela segunda alternativa. Todo o excurso consistirá, pois, numa série de passos que, paulatim sed firmiter, pretendem desbravar o caminho que conduz à definitiva concepção augustiniana da vida como deserto. Pede-se, por isso, muita paciência.

Dê-se então o primeiro passo.

É bem conhecida a identificação do Homem como imagem de Deus. Mas o que é que isto significa ao certo? Quais as suas implicações? E, antes de qualquer outra consideração, o que é ser imagem? Cabe também aqui o dito aplicado por Agostinho ao problema da saber o que é o tempo: «se ninguém me pergunta, eu sei; se alguém me pedir que explique, não sei». ${ }^{11}$ De facto, esta é uma identificação que, sob o manto de uma aparente clarividência, deixa ainda folga para uma grande margem de obscuridade quanto àquilo que significa e quanto àquilo que implica.

Não é este o lugar para produzir um estudo exaustivo da noção de imagem. Terá de se deixar de lado até mesmo aspectos nucleares daquele conceito. As diligências que vão ser feitas têm como único fito encaminhar para a compreensão da vida como deserto. Nesta perspectiva, pode-se definir a imagem como uma existência marcada por tal semelhança de outro que a própria existência é participação desse outro de que se é semelhança. ${ }^{12}$ Assim, o facto de o Homem ser imagem remete, por um lado, para a sua dimensão de proveniência: é o seu próprio ser que provém. Trata-se de algo recebido. O Homem depende inteiramente de uma doação de ser. Mas, por outro lado, o referente de que é imagem implica que a doação de ser seja tal que constitui participação de Deus. Enquanto todas as outras realidades são vestígios, os homens são imagens. Participam do próprio Deus. ${ }^{13}$

Agora pergunta-se: o que é que isto significa ao certo?

11 Idem, Confessiones XI, XIV, 17: «si memo ex me quaerat, scio; si quarenti explicare velim, nescio».

12 Reafirme-se que esta definição não pretende ser exaustiva. Deixa de lado, por exemplo, um aspecto tão decisivo como o facto de a imagem abarcar não apenas o conceito de semelhança mas também o conceito de expressão. É também de notar que (dado o seu carácter homilético) as próprias Enarrationes não contêm uma definição exaustiva. Esta é avançada noutras obras. Desde logo, no De trinitate. Mas, também, na questão 74 do livro De diversis qucestiones octoginta tribus, onde é apresentada a teoria augustiniana não só sobre o conceito de imagem mas também sobre os conceitos de igualdade e de semelhança.

13 À semelhança do que sucede noutros textos do corpus augustinianum, o conceito de participação atravessa todas as Enarrationes. Cfr., a título de exemplos, idem, Enarrationes in psalmos, 7, n. $^{\circ} 8 ; i b i, 29$, p. II, n. $^{\circ} 2 ; i b i, 70$, s. I, n. ${ }^{\circ} 2 ; i b i, 120$, n. $^{\circ} 5 ; i b i$, 121 , passim; ibi, 134, n. ${ }^{\circ} 4 ;$ ibi, 138, n. $^{\circ} 2$; e ibi, 146, n. ${ }^{\circ} 11$. 
Nas Enarrationes, a dimensão do Homem identificada como sede da imagem propriamente dita é, quase sempre, a razão. Dizer que o Homem é imagem de Deus equivale quase sempre, nas Enarrationes, a dizer que é capaz de razão. Escreve Agostinho no sermão ao salmo 42: «percebemos ter em nós algo onde está a imagem de Deus, a saber: a mente ou razão». ${ }^{14} \mathrm{E}$ aprofunda a mesma ideia no segundo sermão ao salmo 48 : «vós, irmãos, considerai-vos homens feitos à imagem e semelhança de Deus [...]. A imagem de Deus está no interior, não no corpo. Não está nestes ouvidos que vedes, nem nos narizes, nem no paladar, nem nas mãos, nem nos pés. Mas todavia existe. Onde está a razão, onde está a mente, onde está o motivo para investigar a verdade [...] aí tem Deus a sua imagem». 15

Mas não é nada claro que a razão seja a sede da imagem. Por que não o corpo? Por que não uma qualquer outra dimensão? Agostinho está a apontar para o enorme "milagre" que se dá no Homem pelo facto de ter a possibilidade de aceder não só à totalidade daquilo que o circunda mas também a si próprio. Estes exercícios de reconhecimento e de reflexividade, respectivamente, são de todo excepcionais na criação. $\mathrm{O}$ facto de ser capaz de razão confere ao Homem um poder singular. E tal poder singular instaura a já mencionada participação de Deus. Este poder não lhe é dado por nenhuma outra componente. Enquanto o corpo, por exemplo, é uma dimensão que tem em comum com os animais, a razão instaura no Homem uma excelência única, não partilhada com nenhum outro ser. Isto é, instaura nele uma diferença qualitativa, e não apenas quantitativa. Os homens não se diferenciam dos animais apenas como estes se diferenciam entre si: a sua marca distintiva vai para lá da diferença específica. E é precisamente o facto de serem imagem que institui neles essa diferença qualitativa: «De entre as muitas tribulações deste mundo, este salmo de inteligência lamenta algo. Mas não chora com ele quem não dispõe de razão. Ora nós, caríssimos, devemos ter presente que fomos feitos à imagem de Deus, e não devemos ver a imagem em nada mais a não ser na razão. De facto, somos superados em muitas coisas pelas bestas; mas quando o Homem sabe que foi feito à imagem de Deus, então reconhece em si algo que é maior do que o que foi dado aos animais. Na verdade,

${ }^{14} \mathrm{Ibi}, 42, \mathrm{n}^{\circ}$ 6: «intelligimus habere nos aliquid ubi imago Dei est, mentem scilicet atque rationem».

$15 \mathrm{Ibi}, 48$, s. II, n. ${ }^{\circ}$ 11: «vos autem, fratres, considerate vos homines factos ad imaginem et similitudinem Dei [...]. Imago Dei intus est, non est in corpore: non est in auribus istis quas videtis, et naribus, et palato, et manibus, et pedibus: sed est facta tamen: ubi est intellectus, ubi est mens, ubi ratio invetigandæ veritatis [...] ibi habet Deus imaginem suam». 
ao considerar todas as coisas que o constituem, o Homem reconhece que se distingue dos animais, de modo único, porque dispõe de razão». ${ }^{16}$

Numa tentativa de dar mais um passo, é conveniente ceder a palavra a Agostinho, ainda durante mais algum tempo: «existe em todos um não sei quê de invisível, que se chama espírito ou alma, que convida todos os seres vivos a ir ao encalço do prazer e a fugir do incómodo, a conservar na sua integridade um certo vestígio de unidade. Também existe no Homem algo em comum com os anjos de Deus. Não o que existe em comum com os animais, como viver, ouvir, ver, e outras coisas - mas sim conhecer Deus, que pertence de modo próprio à mente. Pois assim como o olho distingue o branco do preto, assim também ela distingue a justiça da injustiça. [...] Ouço, creio, entendo na medida em que posso que Deus é visto com o coração, e que nada além do coração o pode contemplar no mundo. [...] E quando é que me compreendo a mim em mim? Por onde posso compreender o que está sobre mim? Mas é prometido ao coração humano a visão de Deus, e é-lhe indicado um certo acto de pureza do coração. [...] Portanto, sempre que a alma humana se aproxima, o homem interior é recreado à imagem de Deus, pois foi criado à imagem de Deus»». ${ }^{17}$ Neste excerto do sermão ao salmo 99, figuram alguns dos tópicos fundamentais da análise antropológica presente nas Enarrationes: a oposição entre vestígio e imagem; a concepção augustiniana da reflexividade; a noção de homem interior (que sugere a existência de um homem exterior); entre outros aspectos que não cabe referir. No presente contexto, importa destacar um elemento decisivo do que neles se acha em causa: a circunstância de a imagem envolver um sobredimensionamento

$16 \mathrm{Ibi}, 54, \mathrm{n}^{\mathrm{o}}$ 3: «Inter multas ergo tribulationes huius sæculi, plangit aliquid psalmus iste de intellectu. Ille cum isto non plorat, qui non habet intellectum. Porro autem, charissimi, meminisse debemus ad imaginem Dei nos esse factos, nec alibi quam in ipso intellectu. Nam in multis rebus a bestiis superamur: ubi autem homo imaginem Dei factum se novit, ibi aliquid in se agnoscit amplius esse quam datum est pecoribus. Consideratis vero omnibus rebus quas habet homo, invenit se eo proprie discretum a pecore, quod ipse habeat intellectum».

$17 \mathrm{Ibi}, 99, \mathrm{n}^{\mathrm{o}}$ 5: «inque his omnibus nescio quid invisibile, quod spiritus vel anima dicitur, inesse omnibus animantibus ad appetendam voluptatem fugiendamque molestiam, ad conservandam incolumitatem suam vestigium quoddam unitatis; inesse etiam homini commune quiddam cum Angelis Dei; non cum pecoribus, sicut est vivere, audire, videre, et cætera, sed quod intelligat Deum, quod ad mentem proprie pertineat, quod sicut oculus album et nigrum, ita æquitatem iniquitatemque discernat. [...] Audio, credo, ut possum intelligo, corde videri Deum, nec posse nisi mundo corde conspici. [...] Et quando comprehendo me in me? Unde ergo possum quod supra me? Promittitur tamen corde humano visio Dei, et indicitur quædam operatio mundandi cordis. [...] Accedit ergo utcumque anima humana, interior homo recreatus ad imaginem Dei, quia creatus ad imaginem Dei». 
constitutivo no Homem. Segundo Agostinho, o facto de os homens terem sido criados à imagem de Deus abre-lhes uma possibilidade que não é conferida a nenhum ente natural: sendo naturezas na medida em que vivem, ouvem, vêm (entre outras faculdades naturais) os homens são todavia uma excepção ao natural. Pois estão como que "feitos para o alto". Estão chamados a ser mais do que aquilo que são.

É justamente esta vocação que faz com que o Homem partilhe algo com os anjos de Deus. A possibilidade de ser mais faz com que cada pessoa esteja constituída em honra. E «o que significa estar constituído em honra? Que o Homem foi posto à frente dos animais, ao ser feito à imagem e semelhança de Deus [...]. Pois Deus não fez o Homem do mesmo modo que fez o jumento; antes fez os jumentos para que servissem o Homem. Mas acaso [para servirem] às suas forças, e não à sua inteligência?». ${ }^{18}$ O tom retórico da pergunta final sublinha o que já foi exposto: o sobredimensionamento tem a sua sede na razão. E esta confere ao Homem um lugar completamente único em toda a esfera do criado: ao dispor de razão, cada homem é, ao limite, capaz de participar inteiramente de Deus.

Neste sentido, vê-se que Agostinho admite a existência do que se pode chamar "endeusamento lícito". Esta forma de endeusamento não envolve uma tentativa de extorquir o lugar que só a Deus pertence. Antes é consequência, precisamente, do desejo de participação naquele que sobredimensiona. Na verdade, as Enarrationes aludem ao facto de ser a trindade - ela própria e sem eufemismos - a querer assentar a sua morada no interior do Homem. Noutros termos: é o próprio referente da imagem que, a partir da razão, chama à visão de si. De modo a desenvolver, assim, todas as possibilidades de sobredimensionamento.

No entanto, as passagens indicadas devem ser lidas com cuidado, sob pena de não se captar o que realmente se acha em jogo nelas. Uma leitura apressada pode dar a entender que só a razão expressa a imagem de Deus. E nada é mais contrário à tese presente nas Enarrationes. Sem dúvida que a sede da imagem reside tão-só na razão. Agostinho di-lo de modo claro, como se viu. Mas enganar-se-ia quem concluísse que este facto anula a possibilidade de as outras componentes do Homem serem expressão da imagem. Uma coisa é ser sede da imagem, outra é dela ser expressão. A sede da imagem expressa-a sempre, mas uma expressão da imagem nem sempre vem daquela que é a sua sede. Na verdade, muito além de não se esgotarem na razão, as expressões da imagem são tantas

$18 \mathrm{Ibi}, 48$, s. I, n. ${ }^{\circ}$ 16: «quid est, in honore positus? Factus ad imaginem et similitudinem Dei, homo prælatus iumentis [...]. Non enim fecit Deus sic hominem, quomodo fecit iumentum; sed fecit Deus hominem cui servierent iumenta: numquid eius viribus, et non intellectui?». 
quantas as dimensões do Homem. Quer dizer, a imagem não deixa absolutamente nenhuma componente fora da sua esfera: a partir da razão, como que "alastra" a todas as dimensões constituintes do Homem. Neste sentido, quando Agostinho diz que a imagem de Deus não está no corpo, tal afirmação deve ser entendida apenas no sentido em que o corpo não é sede da imagem. E, de facto, considerado isoladamente, não extravasa $\mathrm{o}$ plano exterior (i.e., do «foris»), sendo património comum ao Homem e aos animais. $\mathrm{O}$ mesmo se aplica à escala categorial: o ser, o viver e o sentir são momentos da escala que, considerados em si mesmos, são partilhados com os animais. Todavia, Agostinho considera que estas dimensões não podem ser tomadas apenas em si mesmas, de modo isolado ou abstracto: têm de ser vistas como dimensões que expressam a imagem de Deus. E que, por conseguinte, detêm no Homem um carácter transitivo.

Aplique-se o exposto à escala categorial. Como se disse, o ser, o viver e o sentir são momentos da escala que, considerados isoladamente, constituem património comum aos homens e aos animais. Mas sucede que, no Homem, estes ser, viver e sentir são um ser, um viver e um sentir de uma existência que é imagem. Remetem, portanto, para aquela que é a sua sede - isto é, enviam para o plano superior do entendimento. À luz destes elementos, percebe-se, em toda a sua amplitude, a exortação de Agostinho presente num comentário ao décimo segundo versículo do salmo 115. Pergunta-se naquele versículo: «Como retribuirei ao Senhor todos os seus benefícios para comigo?». ${ }^{19} \mathrm{E}$ Agostinho comenta: «Por que benefícios? Primeiro, porque és: mas também a pedra é. Depois, porque vives: mas também o animal vive. O que retribuirás ao Senhor, por te ter feito à sua imagem e semelhança, acima de todas as bestas e acima de todas as aves?». ${ }^{20}$ Com efeito, já o plano do ser é no Homem expressão da imagem, de tal modo que ele deve agradecer primeiro porque é. O plano do viver também é dela expressão, e reclama agradecimento. No entanto, consideradas isoladamente, estas dimensões são partilhadas com as bestas. Não são a sede da imagem. Assim, o principal benefício que o Homem deve agradecer é aquele que não só o coloca num plano eminente em toda a criação mas também transfigura estes outros planos, conferindo-lhes um

$19 \mathrm{Ibi}, 102$, n. $^{\circ}$ 3: «Quid retribuam Domino, pro omnibus [...] quæ retribuit mihi».

20 Ibidem: «Pro quibus bonis? Primo, quia es: sed est et lapis. Deinde, quia vivis: sed vivit et pecus. Quid retribues Domino, pro eo quod super omnia pecora et super omnia volatilia fecit te ad imaginem et similitudinem suam?». O itálico é meu, e pretende destacar as referências explícitas aos momentos da escala categorial. Não se estranhe o facto de Agostinho comentar um versículo do salmo 115 no sermão ao salmo 102. Trata-se de um método recorrente nas Enarrationes: para clarificar um versículo, chama outros até si, e muitos deles não são do salmo em análise. 
carácter transitivo. Que plano é esse? Segundo Agostinho, é o plano da razão, do entendimento - da imagem.

Mas a dimensão a partir da qual esta tese mais se encontra tratada nas Enarrationes é, sem sombra de dúvidas, a dimensão corporal. Também o corpo do Homem é um corpo transfigurado, porque é corpo de uma existência que é imagem. ${ }^{21}$ É neste sentido que se deve entender a oposição entre estado recto («status rectus») e estado curvo («status curvus»), repetida por Agostinho até à exaustão. ${ }^{22}$ Já os Antigos tomavam a estatura corporal erecta como uma das marcas distintivas do Homem: é porque o seu corpo está em posição erecta que ele pode olhar para diante e para o alto. ${ }^{23}$ Ora, esta estatura do corpo e as suas implicações são tomadas por Agostinho como expressão da imagem na dimensão corporal. Assim, o estado recto é considerado expressão de uma capacidade humana fundamental, a saber: a possibilidade de transcendência - de sobredimensionamento. Esta não é uma expressão de somenos importância. Simboliza a tese augustiniana segundo a qual o Homem está como que "feito para o alto". Sendo justamente este achar-se "feito para o alto" que o diferencia, de modo qualitativo, de todos os animais.

\section{O desbotamento da imagem como curvatura do Homem:}

Feito este brevíssimo estudo da imagem de Deus como sobredimensionamento do Homem, estão criadas as condições para dar mais um passo decisivo em direcção à concepção augustiniana da vida como deserto. Tal passo tem que ver com a circunstância de, à postura fisicamente erecta do corpo ${ }^{24}$ Agostinho contrapor insistentemente um estado curvo da alma. O número de referências a esta oposição («status rectus» - «status curvus») só encontra paralelo nas alusões ao conceito teológico de Cristo total. São tantas as passagens em que Agostinho refere a imagem da

21 Cfr. $i b i, 97$, n. $^{\circ} 1$.

22 Cfr., a título de exemplos, ibi, 7, n. ${ }^{\circ} 11 ; i b i, 16$, n. $^{\circ} 10 ; i b i, 24$, passim; ibi, 31, p. I, n. ${ }^{\circ} 11 ; i b i, 36$, s. I, n. ${ }^{\circ} 12 ; i b i, 37$, n. ${ }^{\circ} 10 ; i b i, 38,{ }^{\circ}{ }^{\circ} 1 ; i b i, 65,{ }^{\circ}{ }^{\circ} 16 ; i b i, 68$, s. II, n. ${ }^{\circ} 8 ; i b i, 77,{ }^{\circ}{ }^{\circ} 10$ e n. ${ }^{\circ} 21 ; i b i, 89$, n. $^{\circ} 17 ; i b i, 93$, n. $^{\circ} 18 ; i b i, 96$, n. ${ }^{\circ} 18 ; i b i, 100$, n. ${ }^{\circ} 6 ; i b i, 111$, n. ${ }^{\text {os }} 3-4 ; i b i, 124$, n. $^{\circ} 2 ; i b i, 139,{ }^{\circ}{ }^{\circ} 18 ; 142, n{ }^{\circ} 5$; e $i b i, 146$, n. ${ }^{\circ} 5$ e 7.

23 A este propósito, cfr., por exemplo, ROSELLI, A., «Il volto e le mani. Materiali per un commento a Greg. Nyss. De hominis opificio (PG 44, pp. 144-9)», in L'homme grec face à la nature et face à lui-même, ed. J.-M., Galy et al., Association des Publications de la Faculté des Lettres de Nice, Nice, 2000, pp. 323-40, em particular pp. 323-8.

24 Escreve-se "postura fisicamente erecta do corpo" porque, como se verá, a dimensão corporal caracteriza-se por um outro tipo de curvatura. 
curvatura $^{25}$ que é de todo impossível analisar, em pormenor, as especificidades presentes em cada uma delas. No entanto, o seu tratamento nas Enarrationes é susceptível de uma sistematização em três vertentes fundamentais.

A primeira vertente pode ser descrita como a perda do estado recto da alma. Agostinho considera que a queda original foi motivada por um amor desordenado ${ }^{26}$ : um amor do Homem por si, até ao desprezo do próprio Deus. ${ }^{27} \mathrm{E}$ um amor tal por si que o Homem chegou ao ponto de querer tornar-se deus fora da participação naquele que sobredimensiona. Isto é, rejeitou o "endeusamento lícito" (desejado pela trindade), e optou por uma forma de "endeusamento ilícito". O qual, longe de abrir as portas a um verdadeiro endeusamento, só pôde ter como resultado uma perda da postura original da alma. Por outras palavras, a curvatura da alma resultou de um desejo do bem de si, em detrimento do bem em si. Este facto pode ser entendido quando posto em contraste com a definição augustiniana do estado recto da alma: «O coração [...] é recto para com Deus quando quer Deus por Deus (propter Deum»)».28 A curvatura nesta primeira vertente consiste, pois, em querer o bem por outro («propter aliud») que não Deus. Mais concretamente, consiste em querê-lo por si («propter se»). Nasceu, portanto, da circunstância de se querer fruir dos bens particulares, em detrimento daquele que, na ordem, é o objecto próprio da fruição. Justamente: consistiu num amor do bem (particular) de si, até ao desprezo do bem em si. ${ }^{29}$ Ao ponto de, no seu estado presente, o Homem querer torcer até mesmo a vontade de Deus, em vez de ceder na vontade própria. O que acaba por acontecer é que o Homem, ao querê-lo, torce ainda mais a sua própria alma. Até porque a vontade de Deus é insusceptível de ser

25 Ver nota 22.

26 A propósito da noção de ordem, bem como dos seus nexos com o conceito de queda, cfr. ROSA, J. M. S., Em busca do centro - Investigações sobre a noção de ordem na obra de Santo Agostinho (Periodo de Cassicíaco), Universidade Católica Editora, Lisboa, 1999; e SILVA, P. O., Ordem e ser - Ontologia da relação em Santo Agostinho, Centro de Filosofia da Universidade de Lisboa, Braga, 2007.

27 A este propósito, cfr. O’DONOVAN, O., The Problem of Self-Love in St. Augustine, Wipf and Stock Publishers, Eugene, 2006.

28 AGOSTINHO, Enarrationes in psalmos, 77, n. ${ }^{\circ}$ 21: «Rectum [... cor cum Deo est, quando propter Deum quærit Deum» Itálico meu.

29 A propósito da oposição «uti» - «frui», cfr. ibi, 4, n. ${ }^{\circ} 8 ; i b i, 102,{ }^{\circ}{ }^{\circ} 8 ; i b i, 121$, n. ${ }^{\circ} 3$; ibi, 139, n. ${ }^{\circ} 10$; e ibi, 143, n. ${ }^{\circ}$ 18. Cfr., ainda, OSBORNE, T., Love of Self and Love of God in Thirteenth-Century Ethics, University of Notre Dame Press, Notre Dame, 2005 , passim. O título da obra pode induzir em erro. Na verdade, o autor não se limita a investigar o modo como o problema é encarado no século XIII. Por exemplo, as páginas 13-23 são exclusivamente dedicadas à solução augustiniana. 
torcida: «De facto, se não queres aquilo que Deus quer, serás curvo, e a tua perversidade não te permitirá estar voltado para o recto» ${ }^{30} \mathrm{E}$ ainda: "Quando queres uma coisa e Deus quer outra, és de coração torcido e de vontade perversa. [...] Não queiras torcer a vontade de Deus até à tua vontade, mas antes corrige a tua de acordo com a vontade de Deus. A vontade de Deus é como uma regra: olha, pensa que torceste a regra; onde poderás corrigir-te? Mas ela permanece íntegra, pois a regra é inalterável. [...] Todavia, o que querem os homens? Não lhes basta terem a sua vontade torcida: também querem torcer a vontade de Deus até ao coração deles - para que Deus faça o que querem». ${ }^{31}$

Esta primeira vertente da curvatura implica uma segunda: a curvatura do corpo. Agostinho considera que a curvatura primeira da alma, na queda original, implicou esta segunda. ${ }^{32}$ Este ponto é decisivo. No que precede, viu-se que o Homem está como que "feito para o alto", pois é capaz de razão - é imagem de Deus. Viu-se também que uma clara expressão da

${ }^{30} \mathrm{Ibi}, 36$, s. I, n. ${ }^{\circ} 12$ : «Nam, si tu nolis quod Deus vult, curvus eris, et pravitas tua non te permittet planari recto».

$31 \mathrm{Ibi}, 93, \mathrm{n}^{\circ}$ 18: «Distorti cordi es et pravæ voluntatis, quando aliud vis, aliud vult Deus. [...] Ne voluntatem Dei velis torquere ad voluntatem tuam, sed tuam corrige ad voluntatem Dei. Voluntas Dei sic est quomodo regula: ecce, puta, torsisti regulam; unde habes corrigi? Illa autem integra manet: regula est enim incommutabilis. [...] Quid autem volunt homines? Parum est, quia voluntatem suam tortuosam habent; etiam volunt voluntatem Dei tortam facere secundum cor suum, ut hoc faciat Deus quod ipsi volunt». Cfr., também, ibi, 96, n. ${ }^{\circ} 18$.

Estes elementos mostram que, segundo Agostinho, a curvatura da alma não é o constitutivo da natureza. Trata-se "apenas" de uma consequência da queda original. No desenvolvimento posterior da imagem da curvatura, surgirão vários autores a defender a posição contrária. Assumindo-se a escola franciscana como a corrente filosófico-teológica que mais sustenta a tese da constitutiva curvatura da natureza. Duns Escoto chega mesmo a dizer - na Ordinatio IV, d. 49, q. 10, n. ${ }^{\circ} 447$ (ed. Wadding) - que «a natureza não pode permanecer natureza senão enquanto inclinada para a sua perfeição, pois se lhe tiras tal inclinação, tiras-lhe a natureza» («natura non potest remanere natura, quin inclinetur ad suam perfectionem, quia si tollas illam inclinationem, tollis naturam»). Vários autores contemporâneos seguiram esta tese. Para um estudo do desenvolvimento contemporâneo da noção de curvatura, cfr. JENSON, M., The Gravity of Sin - Augustine, Luther and Barth on 'Homo incurvatus in se', T\&T Clark, Londres, 2006, pp. 47-191.

32 O exposto mostra que, segundo Agostinho, a curvatura do corpo não é causa, mas sim consequência da queda original. Como se indicou, o desbotamento da imagem consistiu primeiramente numa curvatura da alma. Contra qualquer concepção da queda original como sendo primordialmente um pecado do corpo, Agostinho põe em evidência, no De civitate dei (XIV, 13), que «não foi a carne corruptível que tornou pecadora a alma, mas foi a alma pecadora que tornou o corpo corrutível» («[...] nec caro corruptibilis animam peccatricem, sed anima peccatrix fecit esse corruptibilem carnem»). 
imagem é o estado fisicamente recto do corpo, o qual é adoptado por Agostinho como símbolo da possibilidade humana de transcendência. Ora, o que acabou de ser estudado obriga a dar mais um passo, que consiste no seguinte: o poder expressado pela dimensão corporal foi como que "obstaculizado" pela desordem na alma. De facto, ao não manter a sua estatura própria, a alma colocou um "entrave" à possibilidade humana de ser mais. A própria possibilidade de transcendência, simbolizada pela dimensão corporal, ficou posta em xeque.

Assim se chega à terceira vertente da curvatura. Esta é desencadeada pelo que se pode chamar "fenómeno da vinculação a si". Tal fenómeno tem por raiz o facto de os homens não estarem na vida como espectadores de bancada. Pelo contrário: estão decisivamente envolvidos no seu acontecimento. Quer dizer, o ponto de vista humano não é especulativo, mas sim interessado nas possibilidades de ii $^{33} \mathrm{E}$ não apenas nas possibilidades de si de modo abstracto, ou indiferenciado. Cada homem está interessado nas melhores possibilidades de desincumbência de si. É o que Agostinho diz, por exemplo, no segundo sermão ao salmo 32: «Queres ser melhor do que és, eu sei, todos o queremos».$^{34}$ Constituem-se assim focos de tensão, dependentes do rumo que cada um dá à sua vida. A tese segundo a qual os homens estão constituídos na possibilidade de serem mais encontra, neste contexto, o seu sentido pleno. Com efeito, a circunstância de se estar como que "feito para o alto" significa que se está atravessado, de todo em todo, por um interesse de maximização. Justamente por estar feito na possibilidade de ser mais, o Homem não identifica apenas as diversas possibilidades de consumação do seu projecto vital. Antes está naturalmente empenhado em escolher aquelas que se lhe afiguram como as melhores possibilidades para a desincumbência de si.

É fácil captar a ligação, íntima e decisiva, entre as três vertentes da curvatura sumariamente analisadas. De facto, o que caracteriza a concepção de Agostinho (como aliás a de toda a filosofia medieval) é que a perda do estado recto da alma e a consequente curvatura do corpo se dão nesta

33 Como fica claro pela oposição estabelecida, o uso que aqui se faz do termo "especulativo" nada tem que ver com o conceito grego de « $\langle\varepsilon \rho 1 \omega \pi \eta ́$ " (nem com o seu equivalente latino: «specula»). Isto é, nada tem que ver com a ideia de um acesso desangulado, menos fechado e a que corresponde um "espectáculo" mais abrangente ou até mesmo omni-abarcante - uma espécie de "ângulo total", desprendido de qualquer ponto de vista. A noção de "especulativo" que aqui se usa opõe-se a "interessado". Um especulativo neste sentido é um espectador, o qual como que "assiste ao desenrolar do acontecimento de si". Segue "aquilo para que lhe dá", como poderia ter seguido o contrário, já que não é puxado por nenhuma possibilidade de desincumbência de si.

${ }^{34} \mathrm{Ibi}, 32$, p. II, s. II, n. ${ }^{\circ}$ 15: «Melior te vis esse, novi, omnes volumus». Itálico meu. 
sujeição à vinculação a si. Noutros termos, as duas primeiras vertentes brotam deste interesse primordial que o Homem tem pela maximização de si. Ao ponto de relegar o bem em si (objecto próprio da fruição) para segundo ou terceiro plano. Na exacta medida em que está "feito para o alto", o Homem (diferentemente do que acontece com os animais) perde a sua estatura própria quando, nesta terceira vertente, se curva sobre si.

Se se partir desta expressão da imagem de Deus para a sua própria sede, a tese augustiniana faz-se ver numa descrição ainda mais gráfica: «Na tua alma está a imagem de Deus. A mente do homem contém-na. Recebeu-a e, inclinando-se para o pecado, desbotou- $a \gg .{ }^{35}$ Quer dizer, a queda em que cada homem se encontra desde sempre já funda-se naquilo que, em terminologia técnica, Agostinho chama «desvio da imagem» («deflexio imaginis»); e, de forma mais descritiva, considera ser um desbotamento da imagem. De tal modo que, em seu estado actual, a mente do Homem é uma «mente corrompida». ${ }^{36} \mathrm{E}$ o pensamento de uma mente em tal estado é, também ele, um pensamento torcido. ${ }^{37}$ Certamente que a proveniência e a constitutiva participação de Deus instauram um dever: se não se volta para o alto, é o próprio Homem que degenera. Mas, segundo Agostinho, tal dever já não é acompanhado pelo poder - na justa medida em que a imagem está desbotada; na exacta medida em que a mente está corrompida, e o pensamento se encontra torcido.

Este facto é tanto mais complexo quanto, em sua génese, não parte nem depende do indivíduo. Trata-se da condição humana, "pro statu isto». Quer dizer, ao aceder a si, o indivíduo compreende-se neste estado, desde sempre já e de cada vez. Nas palavras de Agostinho, experimenta-se como um «desertor de Deus», ${ }^{38}$ como «inquilino» ${ }^{39}$ que «peregrina» ${ }^{40}$ numa «região longínqua». ${ }^{41}$

A adopção destes termos e expressões por parte de Agostinho não é fruto do acaso. Em primeiro lugar, à imagem da deserção subjaz a ideia de fuga àquele que é o lugar próprio. Um desertor de guerra é aquele que abandona o seu posto. Do mesmo modo, a desordem da alma reside em

$35 \mathrm{Ibi}, 32$, p. II, s. II, 16: «In animo tuo est imago Dei, mens hominis capit eam. Accepit eam, et inclinando se ad peccatum decoloravit eam». Itálico meu.

36 A propósito da noção de «corrupta mens», cfr. ibi, 43, n. ${ }^{\circ} 16$. Cfr., também, ibi, 106, n. ${ }^{\circ} 11$, onde Agostinho introduz a ideia de «quædam corruptela mentis».

37 Cfr. ibi, 31, p. II, n. ${ }^{\circ} 1$.

38 Cfr. $i b i, 24$, n. $^{\circ} 2$.

${ }^{39}$ Cfr. $i b i, 119$, n. $^{\circ} 6$; ibi, 131, n. $^{\circ} 10$; e ibi, 148, n. $^{\circ} 11$.

40 Cfr., por exemplo, ibi, 47, n. ${ }^{\circ} 2$; ibi, 55, n. ${ }^{\circ} 9 ; i b i, 60,{ }^{\circ}{ }^{\circ} 3 ; i b i, 66,{ }^{\circ}{ }^{\circ} 5 ; i b i$, 83, n. ${ }^{\circ} 8 ; i b i, 85$, n. $^{\circ} 11 ; i b i, 86$, n. $^{\circ} 9 ; i b i, 93$, n. ${ }^{\circ} 6 ; i b i, 102,{ }^{\circ}{ }^{\circ} 11 ; i b i, 136$, n. ${ }^{\circ} 1$ e n. ${ }^{\circ} 12$; e $i b i, 147,{ }^{\circ}{ }^{\circ} 5$.

${ }^{41}$ Cfr. $i b i, 27$, n. $^{\circ} 5 ; i b i, 47$, n. $^{\circ} 2 ; i b i, 131$, n. $^{\circ} 12$; e $i b i, 138$, n. $^{\circ} 5$. 
abandonar o lugar próprio, o único posto onde pode encontrar autêntico repouso. Em segundo lugar, o inquilino é contraposto ao morador. Assim, quando adopta aquele termo, Agostinho alude a alguém que não está para ficar. A alguém que está de passagem: «[...] também não permanecerei em peregrinação. Emigro daqui; mas chegará o sítio de onde não emigrarei. Pois eu sou inquilino teu na terra, tal como todos os meus pais. Migrarei, portanto, deste inquilinato; mas não emigrarei da morada celeste». ${ }^{42}$ E, ainda de modo mais claro: «Quem de entre nós é inquilino para sempre? Vivemos poucos dias aqui, e passamos. Pois aqui somos inquilinos, no céu seremos habitantes». ${ }^{43}$ Estes excertos enviam para o terceiro termo que Agostinho não usa por acaso, a saber: o termo peregrinação. Trata-se de uma imagem continuamente repetida pelo autor, com as mais diversas aplicações. Assim, por exemplo, o Homem peregrina a caminho da pátria; ${ }^{44}$ ao peregrinar vai construindo a casa na qual será morador; ${ }^{45} \mathrm{em}$ sua peregrinação, experimenta-se no trabalho que parece não ter crepúsculo; ${ }^{46}$ etc. É de relevar, ainda, a aplicabilidade da imagem da peregrinação à ideia de uma travessia fora do lugar próprio. ${ }^{47} \mathrm{Em}$ quarto lugar, ao ouvir-se falar de uma região longínqua, pensa-se de imediato na existência de uma região próxima. Ou seja, pressupõe-se um lugar onde o Homem não mais é desertor, não mais é inquilino, não mais é peregrino - uma região que não pede um outro lugar, porque é o lugar próprio do Homem. Segundo Agostinho, toda a existência humana é um incessante convite a fazer esta travessia. Da «região longínqua» («regio longínqua») para aquela que designa ora de «região da segurança» («regio securitatis»" ${ }^{48}$ ), ora de «região dos vivos» («regio vivorum» ${ }^{49}$ ), ora de «região da verdade imutável» (regio incommutabilis veritatis» $\left.{ }^{50}\right) .{ }^{51}$

$42 \mathrm{Ibi}, 61, \mathrm{n}^{\circ}$ 12: «Neque $[\ldots]$ in peregrinatione mea remanebo: est hic unde emigrem; sed veniam unde non emigrabo. Nam inquilinus ego sum apud te in terra, sicut omnes patres mei. Ergo ab inquilinato migrabo; de domo cælestis non emigrabo».

$43 \mathrm{Ibi}, 60, \mathrm{n} .{ }^{\circ}$ 6: "Quis nostris est inquilinus usque in sæcula? Paucis diebus hic vivimus, et transimus: inquilini enim hic sumus, habitatores in cælo erimus».

44 Cfr., por exemplo (porque as passagens são muitas), ibi, 33, s. II, passim; ibi, 56, n. ${ }^{\circ} 2$; ibi, 61, n. ${ }^{\circ} 7 ; i b i, 72$, n. $^{\circ} 5 ; i b i, 102,{ }^{\circ}{ }^{\circ} 11 ; i b i, 110,{ }^{\circ}{ }^{\circ} 10 ;$ e ibi, 138, n. $^{\circ} 5$.

45 Cfr. $i b i, 29$, p. II, n. ${ }^{\circ} 8$.

${ }^{46}$ Cfr., também, ibi, 69, n. ${ }^{\circ} 9$; ibi, 90, s. II, n. ${ }^{\circ} 1$; e ibi, 110, n. $^{\circ} 7$.

47 Cfr. ibi, 42, n. ${ }^{\circ} 2$.

48 Cfr. $i b i, 85$, n. $^{\circ} 24$

49 Cfr. Ibidem.

50 Cfr. ibi, 58, s. I, 18.

51 Esta imagem é uma clara alusão à parábola do filho pródigo (cfr. $L c \mathrm{XV}, 11-32$ ). 


\section{Experiência da vida como deserto}

Torna-se necessário fazer um levantamento (muito rápido) dos passos fundamentais dados até agora. Posto isso, será finalmente possível levar a cabo uma desformalização ${ }^{52}$ da concepção augustiniana de vida como deserto.

Num primeiro passo, viu-se que a identificação do Homem como imagem de Deus envolvia uma marcada dimensão de sobredimensionamento. O Homem está feito para ser mais. Está até mesmo chamado a sê-lo. É esta a sua tarefa, ou vocação. Contudo, num segundo passo fundamental, o estudo do desbotamento da imagem trouxe consigo imagens de peso - as quais contrastam radicalmente com o convite a ser mais. A deserção, o ser inquilino, a peregrinação, a região longínqua, e até a travessia - todos estes elementos resultantes da curvatura invocam a ideia de um lugar indesejado.

Ora, no seu sentido mais comum, a imagem do deserto corresponde a isso mesmo. O deserto é um sítio solitário, duro, inóspito, onde não se deseja permanecer. Ao descrever a vida como deserto, Agostinho tem isto em linha de conta: dada a condição do Homem, a sua existência é-lhe dada a viver numa «região da miséria». Num lugar onde, por entre gemidos ${ }^{53}$ e tribulações, ${ }^{54}$ cada um corre ${ }^{55} \mathrm{em}$ busca da meta, em busca do referente da imagem - em busca do rosto. ${ }^{56}$

Mas tal referente já não está aí. Já não está dado. Ou melhor: o Homem é que já não está na região da imagem. Afastou-se. Fugiu. Desertou. E o máximo que consegue fazer é deambular, errante, «em imagem»

52 Escreve-se "uma desformalização" porque, na verdade, Agostinho apresenta outra desformalização daquela imagem, a qual não será considerada. Com efeito, as Enarrationes apresentam dois sentidos de "deserto". Por um lado, aquele que será estudado. Por outro, o que se poderia chamar deserto procurado. Este é decorrente de uma experiência de tribulação e de um consequente desejo de fuga ao mundo («contemptus mundi»). Ora, tal desformalização não toca a dimensão constitutiva da vida como deserto. Precisamente: trata-se de um desejo que é decorrente de algo. Para um desenvolvimento deste sentido, cfr. $i b i, 54$, n. ${ }^{\circ}$; e ibi, 64, passim.

${ }^{53}$ Cfr. $i b i, 36$, s. III, n. ${ }^{\circ} 7$; ibi, 48, s. I, n. ${ }^{\circ} 5 ; i b i, 93,{ }^{\circ}{ }^{\circ} 6 ; i b i, 110,{ }^{\circ}{ }^{\circ} 1 ; i b i, 119$, n. ${ }^{\circ} 7 ; i b i, 121,{ }^{\circ}{ }^{\circ} 2 ; i b i, 125,{ }^{\circ}{ }^{\circ} 11 ;$ e $i b i, 148, n{ }^{\text {os }} 4$ e 8 .

54 É quase escusado dizer que esta noção atravessa quase todas as Enarrationes. Referem-se apenas algumas passagens: $i b i, 54$, n. $^{\circ} 3 ; i b i, 68$, s. I, n. ${ }^{\circ} 3 ; i b i, 80$, n. $^{\text {os }} 10-1$; e $i b i, 96$, n. $^{\circ} 7$.

55 Cfr., por exemplo, ibi, 41, n. ${ }^{\circ} 2 ; i b i, 99$, n. $^{\circ} 3$; e $i b i, 121$, n. $^{\circ} 2$

${ }^{56}$ Cfr. $i b i, 12,{ }^{\text {os }} 1-2 ; i b i, 15$, n. $^{\circ} 10 ; i b i, 72,{ }^{\circ}{ }^{\circ} 34$; e $i b i, 104,{ }^{\circ}{ }^{\circ} 3$. 
(«in imagine ${ }^{57}$ ). Assim mesmo: deambular. E deambular errante. Com efeito, não basta dizer que o Homem se encontra no deserto para captar a dimensão mais profunda daquilo para que Agostinho está a chamar a atenção. Na verdade, ao facto de estar no deserto junta-se a angústia de não saber sair dele. O Homem pura e simplesmente não sabe sair do deserto. Esta é, portanto, uma travessia a vários títulos singular. Marcada pela total ausência de referências. Carente de qualquer orientação. Autêntico deambular, errante. Sem saber nem como nem quando. Sem saber onde se está. Para onde se vai. Se se vai. De facto, o deserto não é apenas um sítio solitário, duro, inóspito, onde não se deseja permanecer: é também uma terra sem água. Uma terra onde não está a fonte da vida. Uma terra árida. Sem caminho: «não basta ser deserta, desabitada. Além disso, é sem caminho, sem água. Oxalá o próprio deserto tivesse um caminho! Oxalá um homem ali soubesse por onde sair! Não encontra para seu alívio estradas, pois o deserto delas carece. Portanto, ele erra por ali. Oxalá tivesse água para se refazer, uma vez que não consegue sair! Deserto deplorável, horrível e temível!». ${ }^{58}$

Esta é a terra onde o Homem se encontra, segundo Agostinho. Terra de falta e de pobreza. ${ }^{59}$ Terra de miséria. ${ }^{60}$ Dada a condição de curvatura em que se encontra, desde sempre já e de cada vez, a existência humana chega mesmo a confundir-se com esta categoria: o ser humano é aquele que deve à terra; ${ }^{61} e ́$ aquele que lambe a terra ${ }^{62}-\dot{e}$ um homem curvado. Prostrado. Batido em terra de solidão. ${ }^{63}$ Sulcado em terra árida. ${ }^{64}$

A vida humana é a travessia desta terra - é a travessia do deserto.

57 A este propósito, leia-se $i b i, 38$, n. $^{\circ}$ 11: «Quanquam in imagine ambulat homo. In qua imagine, nisi illius qui dixit: Faciamus hominem ad imaginem et similitudinem nostram? [...] Ideo enim Quanquam, quia magnum aliquid imago hæc. Et hoc Quanquam, secutum est Tamen: ut illud quod audistis Quanquam, ultra solem sit; hoc autem quod sequitur Tamen, sub sole sit; et illud pertineat ad veritatem, hoc ad vanitatem».

$58 \mathrm{Ibi}, 62, \mathrm{n}^{\circ}{ }^{\mathrm{0}}$ 8: «Parum est, deserta, ubi nullus hominum habitat; insuper, et sine via, et sine aqua. Utinem vel viam haberet ipsum desertum! Utinam illuc homo incurrens, vel nosset quia inde exiret! Non videt hominem ad solatium, non videt viam qua careat deserto. Ergo ibi divertit. Utinam esset vel aqua, unde reficeretur, qui inde non potest exire! Malum desertum, horribile et timendum!». Itálico meu.

59 Cfr. $i b i, 83$, n. $^{\circ} 8$; e ibi, 85, n. $^{\circ} 3$.

${ }^{60}$ Cfr. $i b i, 11,{ }^{\circ}{ }^{\circ} 6 ; i b i, 26$, p. II, s.2, n. ${ }^{\circ} 1 ; i b i, 32$, p. II, s. II, n. ${ }^{\circ} 4 ; i b i, 56,{ }^{\circ}{ }^{\circ} 7$; $i b i, 87$, n. $^{\circ} 15$; e $i b i, 101$, n. $^{\circ} 11$.

${ }^{61}$ Cfr. ibi, 23, 8.

62 Cfr. $i b i, 71$, n. $^{\circ} 12$.

63 Cfr. $i b i, 101$, n. $^{\circ} 7$.

${ }^{64}$ Cfr., por exemplo, ibi, 32, p. II, s. II, n. ${ }^{\circ}$ 9; ibi, 46, passim; ibi, 67, n. ${ }^{\circ} 31$; e $i b i$, 135, n. $^{\circ} 7$. 
Travessia (peregrinação, a caminho...) que se faz em dias de fome. ${ }^{65}$ Travessia (peregrinação, a caminho...) que se faz em dias de sede. ${ }^{66}$ Como são os dias no deserto.

A experiência da vida como deserto é, justamente, a consciência desta condição, que já atrás se classificou de inexpedível e de inextirpável. Uma condição em que até mesmo as coisas doces da vida são neutralizadas, como também atrás se indicou. É o que Agostinho reitera no segundo sermão ao salmo 48, desta feita a partir de um sinónimo de "deserto", nomeadamente a imagem do exílio: "o senhor da casa é desterrado para o exílio, e tu adornas as paredes da casa. Ele encontra-se necessitado no exílio e desfalece de fome, mal encontra um aposento onde dormir; e tu dizes: "é feliz, pois a casa dele está adornada". Quem não pensará que ou estás a brincar ou estás louco? Adornas o corpo, o espírito é atormentado. Dá algo ao espírito, e deste algo ao morto. Mas que coisa lhe darás, se desejou uma gota de água e não a teve?». ${ }^{67}$

Este tema é aprofundado no sermão ao salmo 41. E o estudo da análise augustiniana daquele salmo é decisivo para se clarificar a sua concepção da vida como deserto. Diz-se no salmo: «Como suspira a corça pelas águas correntes, // assim a minha alma suspira por ti, ó Deus. // A minha alma tem sede de Deus, do Deus vivo! // Quando poderei contemplar a face de Deus? // Dia e noite as lágrimas são o meu alimento, // porque a toda a hora me perguntam: // "onde está o teu Deus?" ». ${ }^{68}$ De que tem sede a corça? De que tem sede o Homem? A resposta de Agostinho, em jeito interpretativo, não se faz esperar: «De que tem sede? Quando virei e verei a face de Deus? É disto que tenho sede: vir e ver [a face de Deus]». ${ }^{69}$ Quer dizer, o Homem tem sede do referente concreto da imagem. É isto que, segundo Agostinho, significa ter sede de Deus. Por outras palavras, significa que todos os homens estão sedentos daquele que sobredimensiona, mas que já não está aí. Que já não está dado, devido à deserção do Homem. Devido à curvatura da alma em que cada homem se encontra desde sempre já, e de cada vez, a existir.

${ }^{65}$ Cfr. $i b i, 32$, p. II, s. II, n. ${ }^{\circ} 25$; e $i b i, 36$, s. II, n. ${ }^{\circ} 8$.

${ }^{66}$ Cfr. ibi, 41, passim; ibi, 55, n. ${ }^{\circ} 7$; ibi, 66, n. ${ }^{\circ} 2$; e ibi, 77, n. ${ }^{\circ} 14$.

${ }^{67} \mathrm{Ibi}, 48$, s. II, n. ${ }^{\circ} 7$ : «[...] dominus domus mittatur in exsilium, et tu ornes paretes ipsius. Ille in exilio eget, et fame deficit, vix sibi unam celam invenit ubi somnum capiat, tu dicis: Felix est, nam ornata est domus illius. Quis te non aut iocari, aut insanire arbitretur? Ornas corpus, torquetur spiritus. Da aliquid spiritui, et dedisti aliquid mortuo. Sed quid illi dabis, quando unam guttam desideravit, et non accipit?»

68 Sl. 41, vv. 2-4.

69 AGOSTINHO, Enarrationes in psalmos, 41, 5: "Quid sitivit? Quando veniam et apparebo ante faciem Dei. Hoc est quod sitio, venire et apparere. Sitio in peregrinatione, sitio in cursu». 
A consciência desta sede envolve, precisamente, a queda em $\mathrm{si} .^{70}$ É neste momento, de reflexividade radical, que cada homem se experimenta na sua derradeira e autêntica dimensão de deserto. É então, neste encontro vital consigo próprio, que cada um se experimenta no abismo ${ }^{71}$ entre aquilo que é pela curvatura (instauradora de falta) e o que podia ser naquele de que é imagem (e que sobredimensiona): «Busco o meu Deus nas coisas visíveis e corpóreas, e não encontro; busco a sua substância em mim próprio, como se fosse algo igual a mim, e também não encontro; sinto que o meu Deus excede a minha alma. Quando tocará a minha alma aquilo que é procurado sobre a minha alma, senão quando a alma se elevar acima de si mesma?».72 No entanto, dado o estado presente de mente corrompida, este voltar-se sobre si próprio apenas pode ter como resultado as lágrimas. Pois o referente da imagem já não está aí à vista: «eu, enquanto não vejo, enquanto difiro, alimento-me dia e noite das minhas lágrimas». ${ }^{73} \mathrm{E}$ é por isso que «a toda a hora me perguntam: // "onde está o teu Deus?"”. ${ }^{74}$

O salmo prossegue com um versículo que desvela, ainda mais, a categoria existencial do deserto e a sua experiência: «A minha alma estremece ao recordar // quando passava em cortejo para a Casa do Senhor, // entre vozes de alegria e de louvor // da multidão em festa». ${ }^{75}$ Está a ser introduzido um tema analisado inúmeras vezes no corpus augustinianum: a recordação. ${ }^{76}$ Por economia de tempo, não se pode produzir uma análise exaustiva de problema tão complexo. No entanto, importa destacar que $a$ experiência de deserto é agudizada pela recordação de que não se está em terra própria. O Homem está aqui, agora, porque foi desterrado da sua casa (na terminologia do salmista, foi desterrado da "Casa do Senhor»). É isto que Agostinho tem em mente ao recorrer, tantas vezes, à oposição entre «casa de habitante» (domus habitatori») e «pousada de viajante» («stabulus viatori») ou, numa versão simplificada, à oposição entre «casa»

70 A propósito da noção de queda em si, cfr., ainda, ibi, 143, n. $^{\circ} 6$.

71 A propósito da noção de abismo, cfr. $i b i, 41$, n. ${ }^{\circ} 13$; e ibi, 134, n. ${ }^{\circ} 16$.

$72 \mathrm{Ibi}, 41, \mathrm{n}^{\circ}{ }^{\mathrm{O}}$ 8: «Quærens ergo Deum meum in rebus visibilibus et corporalibus, et non inveniens; quærens eis substantiam in meipso, quasi sit aliquid qualis ego sum, neque hoc inveniens; aliquid super animam esse sentio esse Deum meum. [...] Quando anima mea contingeret quod super animam meam quæritur, nisi anima super seipsum effundetur?». Itálico meu.

73 Ibidem: «ego quamdiu non video, quamdiu differor, manduco die ac nocte lacrymas meas».

74 Sl. 41, v. 4.

75 Ibi, v. 5.

76 A propósito do conceito de recordação., cfr., por exemplo, AGOSTINHO, Enarrationes in psalmos, 136, passim; ibi, 138, n. ${ }^{\circ} 7$; ibi, 144, n. ${ }^{\circ} 9$; e ibi, 145, n. ${ }^{\circ} 1$. 
e «pousada». O primeiro sermão ao salmo 34 é exemplo paradigmático da primeira versão: «toda esta vida, e todas as coisas que usas nesta vida, devem servir-te de pousada de viajante, não de casa de habitante» ${ }^{77} \mathrm{E}$ o sermão ao salmo 40 alude à segunda: «não ame o viajante a caminho da pátria a pousada em vez da sua casa». ${ }^{78}$ Ambas as versões reenviam para a identificação do Homem como cativo. ${ }^{79}$ Ora, ao experimentar esta que é a sua condição, e ao contrastá-la com a casa para a qual tende, o Homem experimenta uma sede ainda maior. Uma sede na forma de recordação da casa própria.

O cativeiro, bem como o seu nexo com a recordação, são temas retomados no sermão ao salmo 136. E são retomados a partir de outro contraste bíblico que atravessa todas as Enarrationes, a saber: a oposição entre Babilónia e Sião, ou Jerusalém. Em poucas palavras, o contraste entre este mundo de trevas (do homem carnal) e a cidade de Deus (do homem espiritual). ${ }^{80} \mathrm{O}$ Homem está cativo, justamente, porque foi feito para a cidade de Deus (Jerusalém) e está desterrado neste mundo de trevas (Babilónia). Diz o salmo: «Junto aos rios da Babilónia nos sentámos a chorar, // recordando-nos de Sião. // Nos salgueiros das suas margens pendurámos as nossas harpas. // Os que nos levaram para ali cativos // pediam-nos um cântico; // e os nossos opressores, uma canção de alegria: // "Cantai-nos um cântico de Sião." // Como poderíamos nós cantar um cântico ao Senhor, // estando em terra estranha?»». ${ }^{81}$

Além das imagens já estudadas a que estes versículos aludem, importa destacar dois pontos.

Em primeiro lugar, atente-se na expressão "rios de Babilónia". Agostinho adopta-a com um sentido idêntico à imagem do deserto. E não é difícil perceber por quê. Como já se disse, "deserto" e "exílio" são imagens equivalentes. E os rios de Babilónia são, precisamente, o exílio. Pode-se identificar, talvez, uma diferença entre tais imagens: enquanto "deserto" parece remeter para uma travessia que tarda em acabar, "rio" sugere a imagem das águas correntes, que fluem e passam rapidamente. ${ }^{82}$

$77 \mathrm{Ibi}, 34, \mathrm{~s} . \mathrm{I}, \mathrm{n} .^{\mathrm{o}}$ 6: «tota ista vita, et omnia quibus uteris in hac vita, sic tibi debent esse tanquam stabulum viatori, non tanquam domum habitatori». Itálico meu.

$78 \mathrm{ibi}, 40, \mathrm{n}^{\circ}{ }^{\circ}$ : «ne viator tendens ad patriam, stabulum amet pro domo sua». Itálico meu.

79 A propósito da noção de cativeiro, cfr. ibi, 70, s. I, n. ${ }^{\circ} 2 ; i b i, 84$, n. $^{\circ} 3 ; i b i, 110$, n. ${ }^{\circ} 7$; ibi, 125, n. ${ }^{\circ} 1 ; 136$, passim; e ibi, 147, n. ${ }^{\circ} 5$.

80 A propósito desta oposição, cfr., por exemplo (porque as passagens são mesmo muitas), ibi, 51, n. ${ }^{\circ}$ 6; ibi, 61, passim; ibi, 86, passim; ibi, 98, n. ${ }^{\circ} 4$; e ibi, 136, passim.

81 Sl. 136, vv. 1-4.

82 Para um tratamento conjunto das imagens do rio e do deserto, cfr. AGOSTINHO, Enarrationes in psalmos, 65, n. ${ }^{\circ} 11$. 
No entanto, ambas as imagens são tomadas por Agostinho como consequência da curvatura. Também os rios de Babilónia aludem a um amor pelas coisas deste mundo: «Os rios de Babilónia são todas as coisas que se amam aqui e passam». ${ }^{83}$

Em segundo lugar, aqueles versículos deixam bem claro um aspecto apresentado logo no início deste artigo, e que importa agora relevar fortemente. Se se vir bem, o choro junto à margem dos rios de Babilónia não é descrito como um pranto originado por uma qualquer circunstância subjectiva, ou pessoal. É um pranto que se funda na condição de todo um povo. É a própria condição do Homem. A interpretação augustiniana está a vincar, novamente e de modo inequívoco, que a categoria existencial do deserto (do cativeiro, da tribulação, do gemido, de Babilónia...) vai muito mais fundo do que se pode pensar à primeira vista. De tal forma que o choro autêntico não é um choro sem mais: trata-se de um pranto de quem recorda Sião e sabe que tudo passa, flui como um rio, como as águas correntes. Ou seja, o choro junto à margem do rio de Babilónia não depende de algo extrínseco, contrariamente ao choro do homem terreno: «De facto, muitos choram com pranto de Babilónia, porque também se alegram com alegria de Babilónia. Aqueles que se alegram pelo benéfico e choram pelo desfavorável, ambos são de Babilónia. Deves chorar, mas ao recordar Sião. Se choras ao recordar Sião, também deves chorar quando estás bem segundo os critérios de Babilónia». ${ }^{84} \mathrm{E}$ Agostinho prossegue: «Por esta razão se diz num salmo: encontrei a tribulação e a dor, e invoquei o nome do Senhor (Ps. 114, 3 e 4). O que significa dizer encontrei? Não sei como foi procurada a tribulação, mas foi encontrada porque foi procurada. E uma vez encontrada, que benefício surgiu? Invoquei o nome do Senhor. Há uma grande diferença entre encontrares a tribulação e seres encontrado pela tribulação»». ${ }^{85}$

Tudo isto traz consigo um aspecto central. O que Agostinho está a dizer é que a experiência da vida como deserto, muito além de não ser nefasta em si mesma, até deve ser procurada. É o que se acha em causa na diferença entre encontrar a tribulação («invenire tribulationem») e ser

83 Ibidem: «Flumina Babylonis, sunt omnia quæ hic amantur et transeunt».

${ }^{84} \mathrm{Ibi}, \mathrm{n} .^{\circ}$ 5: «Multi enim flent fletu Babylonio, quia et gaudent gaudio Babylonio. Qui gaudent lucris et flent damnis, utrumque de Babylonia est. Flere debes, sed recordando Sion. Si recordando Sion fles, et quando tibi secundo Babylonia bene est oportet ut fleas».

85 Ibidem: «Propterea dicitur in quodam psalmo: Tribulationem et dolorem inveni, et nominem Domini invocavi (Ps 114, 3 et 4). Quid est quod dicit, Inveni? Nesquio quam tribulationem quasi quærendam, invenit tanquam quæsitam. Et cum invenisset, quo lucro invenit? Nomem Domini invocavi. Multum interest utrum invenias tribulationem, an inveniaris a tribulatione». 
encontrado pela tribulação («invenire a tribulatione»). Ser encontrado pela tribulação não passa de um acontecimento passivo - e, enquanto tal, não é da responsabilidade do Homem. Mas encontrá-la, num exercício de reconhecimento e de reflexividade radicais, significa ir activamente ao encalço da condição humana. Significa, portanto, cair em si - e encontrar-se consigo próprio. ${ }^{86}$ Ora, é justamente neste encontro activo do si consigo que se começa a dar o que Agostinho chama «invocação de Deus («invocatio Dei»). ${ }^{87}$ Daí ser tão importante encontrar a tribulação em Babilónia, e não apenas ser encontrado por ela. Chorar junto à sua margem, com pranto autêntico, é desde já um possível recomeço para o endeusamento lícito - para o sobredimensionamento.

Pode-se por isso dizer que, segundo Agostinho, a experiência da vida como deserto abre uma nova possibilidade de voltar à postura recta. Em direcção oposta ao acima estudado desbotamento da imagem, esta experiência trabalha de tal modo o homem interior que se pode mesmo falar de uma reforma da imagem («reformatio imaginis»). ${ }^{88}$ De tal modo que $o$ deserto - por onde o Homem deambulava errante - passa a ter um caminho. É através deste caminho que se torna possivel, finalmente, dar-se o primeiro passo em direcção à pátria.

\section{O deserto de quem se julga fora do deserto:}

No entanto, a experiência da vida como deserto mais não faz do que isto: abrir uma possibilidade. Inaugura um caminho. Abre as portas à eventualidade de dar um primeiro passo em direcção à pátria. Mas é apenas uma possibilidade. O mesmo é dizer que a travessia do deserto ainda está por ser feita. ${ }^{89}$

Esta tese tem de ser sublinhada, de modo inequívoco, porque não raras vezes se pensa que a experiência da vida como deserto é, desde logo e por si só, encaminhamento para a pátria. Nada mais errado. O que tal experiência traz consigo é a percepção da impossibilidade de se estar parado - na justa medida em que se toma consciência de que se está a caminho de algo. Mas não decorre deste facto que o único passo possível seja em direcção à pátria. Quer dizer, todos os homens se encontram, segundo

86 A propósito desta oposição, cfr., ainda, ibi, 137, n. ${ }^{\circ} 12$.

${ }^{87}$ Cfr., a título de mero exemplo, ibi, 143, n. $^{\circ} 12$.

88 A propósito do conceito de «reforma da imagem», bem como de «formação da imagem» («formatio imaginis»), cfr. $i b i, 32$, p. II, s. II, n. ${ }^{\circ} 16 ; i b i, 65,{ }^{\circ}{ }^{\circ} 21 ; i b i, 66$, n. ${ }^{\circ} 4 ; i b i, 70$, s. I, n. ${ }^{\text {os }} 6-10 ; i b i, 140$, n. $^{\circ} 15 ; i b i, 142$, n. $^{\circ} 10 ;$ e $i b i, 146$, n. $^{\circ} 14$.

89 Cfr. ibi, 39, n. ${ }^{\circ} 3$. 
Agostinho, num encaminhamento. Todavia, está nas mãos de cada um decidir qual a forma específica a dar ao encaminhamento. ${ }^{90}$ É possível ao Homem fazer-se mais; mas também pode fazer-se menos. É-lhe possível encaminhar-se para a pátria; mas também pode encaminhar-se para as regiões inferiores e permanecer na errância. De um modo ou de outro, o Homem não deixa de estar é em travessia.

De facto, as Enarrationes, no seu conjunto, constituem uma das primeiras compreensões do Homem como possibilidade. Contrariamente aos animais, os homens nascem nus, ${ }^{91}$ sem nada trazerem consigo para o mundo. ${ }^{92}$ E estão chamados a constituir-se "desta" ou "daquela" forma. Estão, portanto, "em aberto". Numa formulação de cunho eminentemente platónico, ${ }^{93}$ Agostinho afirma que o Homem se encontra numa posição intermédia - a caminho de ser algo que ainda não é. ${ }^{94}$

Ora, o encontro activo do si consigo passa por este reconhecimento de que é possível chegar-se à visão do referente da imagem - mas de que também possivel aumentar a curvatura. Até um ou outro desfecho, a tarefa está dada em aberto. E a autêntica experiência da vida como deserto inclui esta consciência de que ainda se está no exílio.

Quando se fala de uma "autêntica experiência da vida como deserto", subentende-se uma outra experiência, inautêntica. Esta passa, justamente, por o Homem julgar que basta encontrar de modo activo a tribulação para sair do deserto. Por outras palavras, funda-se na ideia de que o Homem pode atingir o referente da imagem já nesta região da miséria - bastando-lhe, para isso, o reconhecimento reflexivo da sua condição. Segundo Agostinho, este é o maior engano no qual se pode incorrer. Porque trata-se da ilusão de que já se está na visão de Deus - trata-se da ilusão de que já não se está no deserto, de que já não se está doente. E, na verdade, «ninguém está mais doente do que quem se julga são». ${ }^{95}$

Tudo isto é um grande engano, desde logo porque parte do pressuposto de que o Homem consegue ir até à pátria por suas próprias forças. Ao dizer-se que basta a experiência do deserto para se começar a sair dele,

90 A este propósito, cfr. ibi, 31, p. II, s. I, n. ${ }^{\circ}$ 6; e $i b i, 36$, s. II, n. ${ }^{o} 16$.

91 Cfr. Job, I, 21.

92 Cfr. I Tm, VI, 7.

93 Cfr. O'DONOVAN, O., op. cit., pp. 100-1.

94 Cfr. AgOSTINHO, Enarrationes in psalmos, 38, n. ${ }^{\circ} 13$; e ibi, 145, n. ${ }^{\circ}$ 5; idem, De libero arbitrio, III, V, 15; ibi, III, XXIII, 71; ibi, III, XXIII, 71; e ibi, III, XIV, 73. O’DONOVAN, O., op. cit., pp. 100-1.

95 AGOSTINHO, Enarrationes in psalmos, 58, s. II, n. ${ }^{\circ}$ 8: «nemo est insabilior eo qui sibi sanus videtur». As referências de Agostinho a esta ilusão são muitas. Cfr., a título de outros exemplos, ibi, 16, n. ${ }^{\circ} 13 ; i b i, 26$, p. II, n. ${ }^{\circ} 6 ; i b i, 29$, p. II, n. ${ }^{\circ} 8 ; i b i, 33$, s. II, n. ${ }^{\circ} 9 ; i b i, 37$, n. $^{\circ} 5 ; i b i, 39$, n. $^{\circ} 3$; e $i b i, 55$, n. $^{\circ} 4$. 
está-se a assumir implicitamente que o Homem é capaz de Deus, por si só e sem mais. Este aspecto pode ser aclarado mediante uma renovada consideração da curvatura. No momento oportuno, viu-se que ela traz consigo a impossibilidade de o Homem cumprir o dever que a sua condição de imagem de Deus lhe institui. Como se viu, a curvatura tem como consequência imediata o facto de o dever não mais ser acompanhado pelo poder. Ora, isso significa que o Homem já não é capaz de rectidão, por sua natureza. É a sua própria natureza decaída que aponta explicitamente para a sua condição de desterrado. Assim, a única via possível para a rectidão é um concurso especial vindo de fora, o qual renove a natureza e lhe devolva o seu estado original. Agostinho não se cansa de repetir que, embora o Homem tenha podido encurvar a sua alma de livre vontade, é incapaz de voltar a endireitá-la por si só e sem mais: «Podes rebaixar-te, mas não podes reerguer-te» ${ }^{96}$. E acrescenta: «Reergue-te quem te fez»..$^{97}$

De facto, segundo Agostinho, todo e qualquer passo efectivo em direcção à pátria tem por requisito uma doação de rectidão ${ }^{98}$ É o próprio referente da imagem que tem de vir ao encontro de cada um, para garantir a reforma da imagem. Não basta, portanto, que o Homem se experimente como deserto. É preciso deixar que a trindade venha ao encontro de cada um e o resgate. Pois só a trindade pode originar um autêntico endeusamento do Homem.

\section{O deserto de quem já está no caminho:}

Mas agora pergunta-se: uma vez consciente o Homem da sua condição, ao querer seguir o caminho que leva à pátria $e$ ao ser-lhe doada $a$ possibilidade de resgate, não se pode assumir que a sua vida já não é um deserto? A resposta é um não rotundo. Por vários motivos.

Em primeiro lugar, porque continua a estar aberta a possibilidade de reincidir no desbotamento da imagem. ${ }^{99}$ É por isso que Agostinho escreve: «Sou necessitado e pobre. Já me foram perdoados os pecados; já comecei a seguir os preceitos de Deus - mas ainda sou necessitado e pobre. Por que motivo és ainda necessitado e pobre? Porque vejo outra lei nos meus membros que se opõe à lei da minha mente (Rom. 7, 23). Por que

96 ibi, 94, n. ${ }^{\circ}$ 10: «A te deficere potes, tu teipsum reficere non potes».

97 Ibidem: «ille reficit qui te fecit». Itálico meu.

98 A propósito da incapacidade de o Homem se endireitar por si e da doação de «rectitudo», cfr., ainda, ibi, 26, p II, n. ${ }^{\circ} 20 ; i b i, 98$, n. $^{\circ} 7 ; i b i, 109$, n. $^{\circ} 1 ; i b i, 125,{ }^{\circ}{ }^{\circ} 2$; ibi, 123, n. $^{\circ} 13 ; i b i, 138$, n. $^{\circ} 13$; e ibi, 144, n. $^{\circ} 9$.

99 Cfr. $i b i, 34$, s. II, n. ${ }^{\circ} 6$; ibi, 120, n. $^{\circ} 11$; e $i b i, 138$, n. $^{\circ} 14$. 
motivo és ainda necessitado e pobre? Porque felizes os que têm fome e sede de justiça (Mt. 5, 6)». ${ }^{100}$ Continua a haver uma travessia do deserto por fazer, por entre fome e sede. Sendo que, no curso desta travessia, o Homem pode alterar a forma do encaminhamento. Também aquele que segue a senda direita tem a possibilidade de recair no caminho curvo.

Em segundo lugar, a vida continua a ser um deserto porque esta é a própria condição do Homem, como já se disse várias vezes. Para aplicar a tese ao caso concreto de quem quer seguir o caminho recto, pode-se começar por citar uma passagem muito significativa. Agostinho propõe-se analisar o décimo primeiro versículo do salmo 101. E afirma: «Porque me elevaste, esmagaste-me. Portanto esmagaste, pois elevaste. Como assim? $\mathrm{O}$ Homem está constituído em honra, foi feito à imagem de Deus. Elevado a esta honra, levantado do pó, erguido da terra, recebeu uma alma racional. Pela excelência da sua razão, foi posto à frente de todas as bestas, animais, aves, peixes [...]. De facto, qual destes tem inteligência? Pois nenhum destes foi feito à imagem de Deus. Assim como nenhum destes tem esta honra, assim também nenhum destes tem esta miséria». ${ }^{101}$

Este excerto é decisivo, desde logo porque compendia em si vários dos temas centrais que foram sendo estudados ao longo do artigo. Fala-se do sobredimensionamento; da forma como este constitui o Homem em honra; do modo como, a partir dele, o Homem é diferenciado qualitativamente dos animais; da sua capacidade de acesso; etc. Mas trata-se de um excerto decisivo por um motivo ainda mais importante: porque aclara o nexo, constitutivo e inalienável, entre o sobredimensionamento e a experiência da vida como deserto. Atente-se nas duas últimas frases: «[...] nenhum destes [animais] foi feito à imagem de Deus. Assim como nenhum destes tem esta honra, assim também nenhum destes tem esta miséria». Isto permite perceber melhor o que se tinha em mente quando, logo no início da exposição, se escreveu que o Espírito é um Espírito que sobredimensiona mas que, justamente ao e por sobredimensionar, instaura

$100 \mathrm{Ibi}, 69$, n. ${ }^{\circ}$ 7: «Ego vero egenus et pauper. Donata sunt mihi peccata; iam copi sequi præcepta Dei: adhuc tamen egenus et pauper. Unde hoc egenus et pauper? Quia video aliam legem in membris meis repugnantem legi mentis mea (Rom. 7, 23). Unde egenus et pauper? Quia, Beati qui esuriunt, et sitiunt iustitiam (Mt 5, 6)». O versículo que Agostinho comenta, e repete no trecho citado, é o v. 6.

$101 \mathrm{Ibi}, 101$, s. I, n. ${ }^{\circ}$ 11: Quoniam levasti, elisisti me. Ideo elisisti, quia levasti. Unde hoc? Homo in honore positus, factus est ad imaginem Dei: levatus in hunc honorem, erectus a pulvere, erectus a terra, accepit animam rationalem, præpositus est rationis ipsius vivacitate omnibus bestiis, pecoribus, volatilibus, piscibus [...]. Quid enim horum habet intelligentiæ rationem? Quia nullum horum factum est ad imaginem Dei. Quomodum nullum horum habet hunc honorem, sic nullum horum habet hac miseriam». Itálico meu. 
em todos os homens uma fortíssima componente de falta, de escassez ou exiguidade - de «ainda não».

Uma componente de falta, de escassez ou exiguidade. Pois o facto de se ir ao encalço do referente da imagem não anula o desamparo que a deserção a Deus trouxe e traz consigo. As coisas doces da vida, além de serem tragadas com amargura, são muito escassas - exíguas mesmo. E o Homem ainda mais exíguo é, em comparação com aquilo que foi e com aquilo que pode ser, na sua pátria, na sua região, naquilo por que anseia noite e dia.

É justamente este anseio (desejo de Deus) que agudiza a experiência de deserto, até ao extremo: "Ainda tenho fome, ainda tenho sede. A minha saciedade aumentou, não diminuiu». ${ }^{102}$ Quer dizer, o facto de $j a ́$ se estar no caminho que leva ao Alto não só não diminui a experiência de deserto, como até a aumenta. ${ }^{103} \mathrm{E}$ este é o último passo que tem de ser dado. A percepção inequívoca de que a vida humana é mesmo um deserto. Sem atenuantes nem paliativos. Sejam quais forem os sucessos da existência. $\mathrm{Na}$ alegria e na tristeza. $\mathrm{Na}$ saúde e na doença. Até que a morte conduza à pátria (ou não, talvez...). Sempre. E se alguém já é conduzido em esperança até à região da imagem, a verdade é que ainda não está nela. Trata-se de um «já», mas na forma de um «ainda não». Justamente: um «já - ainda não»; ou «ainda não - já»: «Resgatou o seu povo como ovelhas, e conduziu-o como um rebanho no deserto. [...] Isto faz-se tanto melhor quanto mais interiormente. É assim que somos tirados do poder das trevas e transferidos para o reino de Deus, e nos fazemos ovelhas de Deus numa pastagem espiritual, andando neste mundo como no deserto». ${ }^{104}$

É bem conhecida a leitura mais comum de passagens como esta. Alega-se logo que a esperança, a fé - a caridade - anulam a configuração da vida como deserto. "Não se está já no caminho certo?" Sim. Mas, neste artigo, conclui-se de modo oposto: se se está no caminho certo, mais certo ainda é que se está no caminho. Numa travessia. Do deserto. Uma leitura das Enarrationes que desconsidere este «ainda não» da vida no exílio é, na verdade, uma leitura apressada. Apressadíssima. Qualquer concepção assente na ideia de que o desterro pode ser ultrapassado nesta

$102 \mathrm{Ibi}, 69, \mathrm{n}^{\circ}$ 7: «Adhuc esurio, adhuc sitio: saturitas mea dilata est; non ablata».

103 Para um desenvolvimento desta mesma ideia, cfr. ibi, 131, n. ${ }^{\circ} 24$; ibi, 137, n. ${ }^{\circ} 13$; e $i b i, 140$, n. $^{\circ} 4$.

$104 \mathrm{Ibi}, 77, \mathrm{n}^{\circ}$ 31: «Et abstulit sicut oves populum suum, et perduxit eos tanquam gregem in deserto. [...] Tanto fit hoc melius, quanto interius, ubi eruti de potestate tenebrarum in regnum Dei mente transferimur, et secundum pascua spiritualia efficimur oves Dei, ambulantes in hoc sceculo velut in deserto». Itálico meu. 
vida só pode dar-se, em última análise, num ponto de vista distraído. Distraidíssimo. Aquém da autêntica compreensão da vida como deserto. Aquém de Agostinho.

Se não se está em erro. 